\title{
Conferencias y Simposios
}

\section{SIMPOSIO 10: Resistencia a la insulina: de la fisiopatología al tratamiento}

Coordinador: Dr. Guillermo Dieuzeide

\section{Tejido adiposo}

Dra. Solange Houssay

Médica, especialista en Diabetes y Nutrición, Hospital Asociado Dr. José María Ramos Mejía, Ciudad Autónoma de Buenos Aires, Argentina

El adipocito capta glucosa estimulado por la insulina, y esta función se vuelve resistente en obesidad y en diabetes mellitus tipo 2 (DM2.) Sin embargo, el tejido adiposo (TA) no es un sitio cuantitativamente significativo de extracción de glucosa estimulada por insulina, representa el $5 \%$ de una carga oral de glucosa en humanos.

A pesar de esto, la deleción órgano específica de GLUT-4 en TA de ratones da como resultado resistencia a la insulina en hígado y ME que apunta a efectos indirectos y fisiológicamente significativos consecuencia de la resistencia a la insulina en la captación de glucosa en el TA.

El efecto insulinosensibilizador global a la insulina de la captación de glucosa en el TA es mediada por ChREBP. La activación de ChREBP promueve la expresión de genes lipogénicos y permite al TA servir de drenaje de nutrientes disminuyendo la entrega de sustratos al hígado y músculo.

La captación de glucosa de los adipocitos genera también glicerol $3 \mathrm{P}$ para la esterificación de los $A G$ al facilitar el almacenamiento de lípidos en TA y reducir su disponibilidad al hígado y músculo.

La asociación entre la expresión de GLUT-4 en el TA y la sensibilidad global a la insulina se atribuyó también a adipokinas como la proteína de unión al retinol RBP 4 y a expresión alterada de nicotinamida $\mathrm{N}$-metiltransferasa.

La lipólisis adiposa es extremadamente sensible a la insulina. El efecto supresor es rápido (10 $\mathrm{min}$ ) en roedores y humanos. La liberación del sustrato lipolítico regula la gluconeogénesis hepática minuto a minuto, y el aumento de la gluconeogénesis es un factor clave de la hiperglucemia en ayunas que define a la DM2.

De esta forma, la exquisita sensibilidad del adipocito a la insulina permite un almacenamiento postprandial ágil y apropiado. Sin embargo, al ser el TA la primera respuesta, sería más vulnerable a la resistencia a la insulina inducida por estrés nutricional ante una sobreoferta de nutrientes. La importancia absoluta de la acción de la insulina en el TA para la homeostasis de la glucosa en todo el cuerpo es poderosa demostrado por la resistencia a la insulina extrema, aunque reversible de la lipodistrofia. Lejos de ser un depósito de almacenamiento inerte, puede de hecho ser el eje de la sensibilidad y la resistencia a la insulina en todo el cuerpo.

Palabras clave: tejido adiposo; diabetes.

\section{Bibliografía}

- Schwartz SS, Epstein S, Corkey BE, et al. The time is right for a New Classification System for Diabetes: Rationale and Implications of the B-Cell-Centric Classification Schema. Diabetes Care 2016;39:179-186.

- Shulman GI. Ectopic Fat in Insulin Resistance, Dyslipidemia, and Cardiometabolic Disease. N Engl J Med 2014;371:1131-41.

- Petersen MC, Shulman GI. Mechanisms of Insulin Action and Insulin Resistance. Physiol Rev 2018; 98:2133-2223.

- Lumeng CN, Saltiel AR. Inflammatory links between obesity and metabolic disease. The Journal of Clinical Investigation. 2011;121(6):2111-2117. 
Revista de la Sociedad Argentina de Diabetes Vol. 54 NN$^{\circ} 3$ Suplemento XXII Congreso Argentino $\& 1^{\circ}$ Congreso Virtual de Diabetes ISSN 0325-5247 (impresa) ISSN 2346-9420 (en línea)

- Archer E, Lavie CJ, Hill JO. The Contributions of "Diet", "Genes" and Physical Activity to the Etiology of Obesity: Contrary Evidence and Consilience Progress in Cardiovascular Diseases 2018; 61(2):89-102. 
SYMPOSIUM 10: Insulin resistance: from pathophysiology to treatment Coordinator: Dr. Guillermo Dieuzeide

\section{Adipose tissue}

Dra. Solange Houssay

Physician, specialist in Diabetes and Nutrition, Hospital Asociado Dr. José María Ramos Mejía, Autonomous City of Buenos Aires, Argentina

The adipocyte uptakes the glucose stimulated by the insulin, and this function becomes resistant in obesity and type 2 diabetes (T2D). However, the adipose tissue (AT) is not a meaningful place of quantity of glucose stimulated by insulin attraction. It represents a $5 \%$ of the oral glucose load in humans.

In spite of this, the organ-specific GLUT-4 deletion in the AT of mice shows as a result insulin resistance in the liver and the skeletal muscle that aims to indirect and physiologically meaningful effects as a consequence of the insulin resistance in the uptake of glucose in the AT.

The global insulin sensitivity effect to the insulin of the glucose uptake in the AT is measured by ChREBP. The ChREBP activation promotes the expression of lipogenic genes, allowing the AT to function as a nutrient drainage, decreasing the delivery of substrates to the liver and the muscle.

The glucose uptake of adipocytes also generates glyceraldehyde 3-phosphate for the esterification of the FA, easing the storage of lipids in the AT and reducing its availability to liver and muscle.

The association between the expression of GLUT-4 in the AT and the global sensitivity to insulin has been attributed also to adipokines such as the retinol-binding protein 4 RBP4 and the altered expression of nicotinamide N-methyltransferase.

The esterification is extremely sensitive to insulin. The suppressor effect is fast (10 minutes) in rodents and humans. The freeing of the lipolytic substrate regulates the hepatic gluconeogenesis by the minute, and the increase of the gluconeogenesis is a key factor of the fasting hyperglycemia that defines the T2D.

This way, the exquisite sensitivity of the adipocyte to insulin allows for an agile and appropriate postprandial storage. However, being AT the first response, it would be more vulnerable to the induced insulin resistance by nutritional stress in light of the oversupply of nutrients. The absolute importance of the insulin action in the AT for the glucose homeostasis in the body is powerful, showing the extreme insulin resistance, although reversible, of the lipodystrophy. Far from being an inert storage depot, it can in fact be the axis of the sensitivity and the insulin resistance in the body.

Key words: adipose tissue; diabetes.

\section{Bibliography}

- Schwartz SS, Epstein S, Corkey BE, et al. The time is right for a New Classification System for Diabetes: Rationale and Implications of the B-Cell-Centric Classification Schema. Diabetes Care 2016;39:179-186.

- Shulman GI. Ectopic Fat in Insulin Resistance, Dyslipidemia, and Cardiometabolic Disease. N Engl J Med 2014;371:1131-41.

- Petersen MC, Shulman GI. Mechanisms of Insulin Action and Insulin Resistance. Physiol Rev 2018; 98:2133-2223.

- Lumeng CN, Saltiel AR. Inflammatory links between obesity and metabolic disease. The Journal of Clinical Investigation. 2011;121(6):2111-2117.

- Archer E, Lavie CJ, Hill JO. The Contributions of "Diet", "Genes" and Physical Activity to the Etiology of Obesity: Contrary Evidence and Consilience Progress in Cardiovascular Diseases 2018; 61(2):89-102. 